\title{
In vitro anti-neoplastic activity of the ethno-pharmaceutical plant Hypericum adenotrichum Spach endemic to Western Turkey
}

\author{
ALI ÖZMEN ${ }^{1,2}$, SABINE BAUER $^{2}$, MANUELA GRIDLING $^{2}$, JUDITH SINGHUBER $^{4}$, \\ STANIMIRA KRASTEVA ${ }^{4}$, SIBYLLE MADLENER ${ }^{2}$, THAN PHUONG NHA VO ${ }^{2,5}$, \\ NICOLE STARK ${ }^{2}$, PHILIPP SAIKO ${ }^{3}$, MONIKA FRITZER-SZEKERES $^{3}$, THOMAS SZEKERES ${ }^{3}$, \\ TÜLAY ASKIN-CELIK ${ }^{1}$, LISELOTTE KRENN ${ }^{4}$ and GEORG KRUPITZA ${ }^{2}$ \\ ${ }^{1}$ Institute of Biology, Fen-Edebiyat Fakültesi, Adnan Menderes Üniversitesi, Aydin, Turkey; \\ ${ }^{2}$ Institute of Clinical Pathology, ${ }^{3}$ Department of Medical and Chemical Laboratory Diagnostics, \\ Medical University of Vienna, Vienna; Departments of ${ }^{4}$ Pharmacognosy and ${ }^{5}$ Pharmaceutical Chemistry, \\ Faculty of Life Sciences, University of Vienna, Vienna, Austria
}

Received February 18, 2009; Accepted May 4, 2009

DOI: 10.3892/or_00000508

\begin{abstract}
Hypericum perforatum (St. John's wort) is wellestablished for its antidepressant activity throughout the world and also various other species within this genus are used in different folk medicines. Hyperforin of St. John's wort inhibited growth of cancer cell lines and the use of hypericin (another compound of $H$. perforatum) in cancer photodynamic therapy is proposed. Therefore, we investigated the anti-cancer properties of $H$. adenotrichum Spach (Guttiferae), an endemic species in Turkey called 'kantaron', which is used for wound healing and antiseptic effects. Freeze-dried plant was extracted with petroleum ether, dichloromethane, ethyl acetate, and methanol and the bioactivity of these extracts was analysed by proliferation assay, cell death determination, by investigating protein expression profiles specific for cell cycle arrest and apoptosis as well as composition by HPLC. The strongest anti-proliferative activity was determined for the petroleum ether extract with an $\mathrm{I}_{\mathrm{p}} \mathrm{C}_{50}$ of $\sim 5.8 \mu \mathrm{g} / \mathrm{ml}$ medium (referring to $1 \mathrm{mg}$ dried plant) which correlated with cyclin D1 suppression and p21 induction. This extract also induced phosphorylation of $\mathrm{H} 2 \mathrm{AX}$, and activated caspase- 3 followed by signature-type cleavage of PARP resulting in $~ 50 \%$ apoptosis at $23.2 \mu \mathrm{g} / \mathrm{ml}$ after $24 \mathrm{~h}$ of treatment. Neither hyperforin, hypericin, or amentoflavone contributed to these properties. To the best of our knowledge, we report for the first time that the endemic plant $H$. adenotrichum Spach exhibits potent p53-
\end{abstract}

Correspondence to: Professor Georg Krupitza, Institute of Clinical Pathology, Medical University of Vienna, Waehringer Guertel 18-20, A-1090 Vienna, Austria

E-mail: georg.krupitza@meduniwien.ac.at

Key words: Hypericum adenotrichum, apoptosis, cell cycle inhibition, cyclin D1, leukaemia independent anti-neoplastic properties due to yet unexplored Hypericum constituents.

\section{Introduction}

Some $60 \%$ of all drugs used in Western medicine are derived from natural compounds which served as leads (1). From the 80 's up to now pharmaceutical companies collect marine organisms, bacteria, fungi and plants at random to test them in robot-screenings regarding their anti-cancer, anti-inflammatory, anti-bacterial etc. activities. Another approach requests the ancient ethno-botanical knowledge of old civilizations which mostly base on the in depth and long lasting empirical experiences with the locally available natural resources, plants at most.

Of the 12,000 plant species in Europe under consideration approximately 11,500 taxa are found in Turkey alone with $33 \%$ of these plants endemic. Since numerous ancient civilisations lived in the area, the plant societies were tested for medicinal applications throughout the ages and many plant species are still used in Turkish folk medicine to treat various diseases (2).

The rich botanical biodiversity of this region paired with the cultural background was the reason to explore the traditional healing plant Hypericum adenotrichum, one of 43 Hypericum species endemic in Turkey. Within the genus Hypericum various species are used in different folk medicines worldwide and are tested against cancer cell growth.

The genus Hypericum is called 'kantaron' in Turkey and $H$. adenotrichum is used in folk medicine for antispasmodic and antiseptic effects, and wound healing especially burns (2). The use of hypericin in cancer photodynamic therapy has been proposed before $(3,4)$. Hyperforin has shown growth inhibition and increased caspase activity in tested cancer cell lines (5). The study of Martarelli et al (6) showed that a methanol extract of $H$. perforatum significantly reduced prostate tumour growth. Five extracts isolated from $H$. hookerianum were tested against the growth of the human 
tumour cell lines MCF-7, NCI-H460 and SF 268. Two extracts exhibited significant inhibitory effects against the three cell lines (7). Wistar rats were grafted with MT-50 mammary carcinoma cells and treated with peri-tumoural injections of hyperforin. Hyperforin significantly inhibited tumour growth, induced apoptosis of tumour cells and reduced tumour vascularisation (8) and restrained tumour invasion and metastasis (9). Methanolic extracts of six Hypericum species from Southern Brazil were screened against two cancer cell lines, HT-29 and H-460. Three of these species were found to be active against cancer cells (10) and a lipophilic extract of $H$. perforatum exhibited anti-neoplastic activity against T24 and NBT-II bladder cancer cells (11). H. adenotrichum Spach is unexplored as yet regarding anti-cancer activities. In a study of 74 taxa of Hypericum, in $H$. adenotrichum rutin, hyperoside, pseudohypericin and hyperforin were not detected, but the species contained amentoflavone (12).

Leukaemia frequently escapes successful treatment when malignant cells are refractory to therapy because of acquired or primary resistance due to e.g. compromised p53 expression. Since new treatment options are urgently needed we investigated the anti-leukaemic properties of $H$. adenotrichum Spach extracts of different polarity in p53-negative HL-60 promyeloic leukaemia cells.

\section{Materials and methods}

Plant material. Hypericum adenotrichum Spach was collected from south-west of Turkey at Karincali mountain (Aydin) at a height of $1422 \mathrm{~m}$ in May 2007. Taxonomic determination was made by Dr Özkan Eren. Voucher specimens, in duplicates were deposited in the herbarium of Department of Biology, Adnan Menderes University.

Sample preparation. The whole plant was freeze-dried, then the plant material was milled and extracted in a solvent-series of increasing polarity (petroleum ether, dichloromethane, ethyl acetate and methanol). Solvent was added 1:10. After the first soxhlet extraction with petroleum ether, filtration and drying of the residues, the dried plant material was subjected sequentially to the second extraction with dichloromethane, the third extraction with ethyl acetate, and fourth extraction with methanol. Extracts were evaporated and yielded 5.8, $10.8,5.3$ and $28.1 \mathrm{mg}$ per g dried plant material (13-15), respectively. The extracts, corresponding to $50 \mathrm{~g}$ dry weight of the plant material, were dissolved in $2 \mathrm{ml}$ ethanol. For the proliferation and apoptosis assay following concentrations as calculated for dried plant material were used: $500 \mu \mathrm{g} / \mathrm{ml}, 1$, 4, $20 \mathrm{mg} / \mathrm{ml}$. Corresponding extract amounts are depicted in Table I. To exclude the effect of ethanol on the cell proliferation and apoptosis, controls were treated with respective concentrations of ethanol as used for sample treatment (in general $\sim 0.4 \% \mathrm{EtOH})$. Increasing concentrations $(0.1,1,5$, $10 \mu \mathrm{M})$ of hyperforin and amentoflavone were used and the effects on cell death, proliferation and protein expression compared to those of the PE-extract.

HPLC analysis. The content of hyperforin and amentoflavone in the extracts was quantified by HPLC (external standardization) as described (12). Column, $5 \mu \mathrm{m}$ Hypersil
Table I. Extract amounts.

\begin{tabular}{lrr}
\hline Extract type & Dried plant $(\mathrm{mg})$ & Extract $(\mu \mathrm{g})$ \\
\hline Petroleum ether & 0.5 & 2.9 \\
& 1 & 5.8 \\
& 4 & 23.2 \\
Dichlormethane & 20 & 116.0 \\
& 0.5 & 5.3 \\
& 1 & 10.5 \\
Ethyl acetate & 4 & 42.0 \\
& 20 & 210.0 \\
& 0.5 & 2.7 \\
& 1 & 5.3 \\
Methanol & 4 & 21.2 \\
& 20 & 106.0 \\
& 0.5 & 14.1 \\
& 1 & 28.1 \\
& 4 & 112.4 \\
& 20 & 562.0 \\
\hline
\end{tabular}

For the proliferation and apoptosis analyses extract concentrations corresponding to $500 \mu \mathrm{g}, 1,4,20 \mathrm{mg} / \mathrm{ml}$ dried plant material were used.

BDS (250x4.6 mm, Shandon, Runcorn, GB); mobile phase, methanol with $1 \%$ acetic acid (v/v) (A) and $1 \%$ acetic acid (B); gradient elution, $0-15$ min $25-55 \%$ A; $15-18$ min 55-70\% A; $18-26 \mathrm{~min} 70 \% \mathrm{~A}$; $26-28 \mathrm{~min} 70-25 \% \mathrm{~A}$; flow rate $1.0 \mathrm{ml} / \mathrm{min}$; wavelength of detection $280 \mathrm{~nm}$. Amentoflavone was only detected in the ethylacetate extract, but the concentration was below the limit of determination of $0.001 \%$. The dichloromethane extract contained hyperforin at a concentration of $0.088 \%$, whereas the other extracts did not contain this substance.

Reagents and antibodies. Hoechst 33258, propidium iodide, and hyperforin were purchased from Sigma. Amentoflavone was from Fluka, and ECL Western Blotting Substrate Cat\# 32106 was from Pierce. Amersham Hyperfilms ECL, High performance chemiluminescence film was from GE-Healthcare. Mouse monoclonal (ascites fluid) anti-acetylated tubulin clone 6-11B1 Cat\# T6793, and mouse monoclonal (ascites fluid) anti- $\beta$-actin clone AC-15 Cat\# A5441, were from Sigma. Rabbit polyclonal anti-cdc25A (M191) Cat\# sc-7157, anti- $\alpha-$ tubulin (TU-02) Cat\# sc-8035, PARP-1 (F-2) Cat\# sc-8007, anti-cyclin D1 (M-20) Cat\# sc-718, and p21 (C-19) Cat\# sc397 were from Santa Cruz Biotechnology Inc. Rabbit monoclonal anti-active caspase-3 (CPP32) clone C92-605 Cat\# 58404 was from Research Diagnostics Inc. Polyclonal antiMEK 1/2 Cat\# 9122, polyclonal anti-phospho-MEK 1/2 (Ser 217/221) Cat\# 9121m, monoclonal rabbit anti-p44/42 MAP Kinase (Erk1/2 137F5) Cat\# 4695, and mouse monoclonal anti-phospho-p44/42 MAPK (Erk1/2-Thr202/Tyr204) (E10) Cat\# 9106 were from Cell Signaling, and rabbit polyclonal 
phospho-detect anti- $\gamma \mathrm{H} 2 \mathrm{AX}$ (pSER139) Cat\# dr-1017 was from Calbiochem. Anti-mouse IgG was from Dako and anti-rabbit IgG from GE-Healthcare.

Cell culture. HL-60 promyeloic leukaemia cells were purchased from ATCC. Cells were grown in RPMI-1640 medium supplemented with $10 \%$ heat inactivated fetal calf serum, $1 \%$ L-glutamine and $1 \%$ penicillin/streptomycin at $37^{\circ} \mathrm{C}$ in a humidified atmosphere containing $5 \%$ $\mathrm{CO}_{2}$. All media and supplements were obtained from Life Technologies.

Proliferation inhibition analysis. HL 60 cells were seeded in T-25 tissue culture flasks at a concentration of $1 \times 10^{5} / \mathrm{ml}$ and incubated with increasing concentrations of plant extracts (corresponding to $500 \mu \mathrm{g} / \mathrm{ml}, 1,4,20 \mathrm{mg} / \mathrm{ml}$ of the drug). Cell counts and $\mathrm{IC}_{50}$ values were determined at 24 and 48 h using a CC-108 microcell counter (Sysmex, Kobe, Japan). Experiments were done in triplicate.

The percent of cell divisions compared to the untreated control were calculated as follows: $\left[\left(\mathrm{C}_{48 \mathrm{~h}+\text { drug }}-\mathrm{C}_{24 \mathrm{~h}+\text { drug }}\right) /\right.$ $\left.\left(\mathrm{C}_{48 \mathrm{~h} \text { - drug }}-\mathrm{C}_{24 \mathrm{~h} \text { - drug }}\right)\right]$ x $100=\%$ cell division, where $\mathrm{C}_{48 \mathrm{~h}+\text { drug }}$ is the cell number after $48 \mathrm{~h}$ of drug treatment, $\mathrm{C}_{24 \mathrm{~h}+\text { drug }}$, is the cell number after $24 \mathrm{~h}$ of drug treatment, $\mathrm{C}_{48 \mathrm{~h} \text { - drug }}$ is the cell number after $48 \mathrm{~h}$ without drug treatment, and $\mathrm{C}_{24 \mathrm{~h} \text { - drug }}$, is the cell number after $24 \mathrm{~h}$ without drug treatment.

Cell death analysis. The Hoechst propidium iodide double staining was performed according to the method described by Grusch et al (16). HL-60 cells $\left(1 \times 10^{5}\right.$ per $\left.\mathrm{ml}\right)$ were seeded in $\mathrm{T}-25$ Nunc tissue culture flask and exposed to increasing concentrations of plant extracts for $24 \mathrm{~h}$. Hoechst 33258 and propidium iodide were added directly to the cells at final concentrations of 5 and $2 \mu \mathrm{g} / \mathrm{ml}$, respectively. After $60 \mathrm{~min}$ of incubation at $37^{\circ} \mathrm{C}$ cells were examined on a Zeiss Axiovert fluorescence microscope equipped with a DAPI filter. Cells were photographed and analysed by visual examination to distinguish between apoptosis and necrosis $(16,17)$. Cells were judged according to their morphology and the integrity of their cell membranes by propidium iodide staining.

Western blotting. HL-60 cells $\left(1.5 \times 10^{7}\right)$ were seeded into T-75 Nunc tissue culture flasks and incubated with selected $23.2 \mu \mathrm{g} / \mathrm{ml}$ PE extract for $0.5,2,4$ and $8 \mathrm{~h}$, respectively. Then, $1 \times 10^{6}$ cells were harvested (per experimental point), washed twice with ice cold PBS, centrifuged at 1,000 rpm for $5 \mathrm{~min}$, lysed in a buffer containing $150 \mathrm{mM} \mathrm{NaCl}, 50 \mathrm{mM}$ Tris pH 8.0,\% 1 Triton-X-100, 1 mM phenylmethylsulfonylfluoride (PMSF) and Protease Inhibitor Cocktail (PIC; from a 100x stock). The lysate was centrifuged at 12,000 rpm for $20 \mathrm{~min}$ at $4^{\circ} \mathrm{C}$, and the supernatant was stored at $-20^{\circ} \mathrm{C}$ until further analysis. Equal amounts of protein samples were separated by polyacrylamide gel electrophoresis (PAGE) and electrotransferred onto PVDF-membranes (Hybond, Amersham) at $4^{\circ} \mathrm{C}$ overnight. Staining membranes with Ponceau $\mathrm{S}$ controlled equal sample loading. After washing with phosphate-buffered saline/Tween-20 (PBS/T) pH 7.2 or Tris buffered saline/Tween-20 (TBS/T) pH 7.6, membranes were blocked for $1 \mathrm{~h}$ in blocking solution (5\% non-fat dry milk in PBS containing 0.5\% Tween-20 or in TBS containing $0.1 \%$ Tween-20). Membranes were incubated with the first antibody (in blocking solution, dilution 1:500-1:1000) by gently rocking at $4^{\circ} \mathrm{C}$, overnight, washed with PBS or TBS and further incubated with the second antibody (peroxidaseconjugated goat anti-rabbit $\mathrm{IgG}$ or anti-mouse $\mathrm{IgG}$, dilution 1:2000-1:5000 in PBS/T or TBS/T) for $12 \mathrm{~h}$. Chemiluminescence was developed by the ECL detection kit (Amersham, UK) and membranes were exposed to Amersham Hyperfilm.

Statistics. All experiments were performed in triplicate and analysed by t-test (GraphPad Prism 4.0 program).

\section{Results}

Induction of caspase-3 and apoptosis by extracts of $H$. adenotrichum. Solvents with increasing polarity (petroleum ether, dichloromethane, ethyl acetate and methanol) were used to extract bioactive constituents from the freeze-dried plant $H$. adenotrichum. The dried extracts were dissolved in ethanol and HL-60 cells were subjected to increasing concentrations of the solutions (Table I). The PE extract elicited predominantly apoptosis. The concentration which induced $50 \%$ apoptosis $\left(\mathrm{AC}_{50}\right)$ was $26.0 \mu \mathrm{g}$ of the dried PE extract per ml cell culture medium (corresponding to $\sim 4.5 \mathrm{mg}$ dried plant material $/ \mathrm{ml}$ medium) after $24 \mathrm{~h}$. The dichloromethane and ethyl acetate extracts were less active $\left(\mathrm{AC}_{50}=136.5\right.$ and $74.2 \mu \mathrm{g}$ extract $/ \mathrm{ml}$ medium, respectively, corresponding to 13.0 and $14.0 \mathrm{mg}$ dried plant material $/ \mathrm{ml}$ ) and induced also necrosis at higher concentrations indicating that these extracts contained compounds with undesired toxicity (Fig. 1a-c). The methanol extract exhibited the weakest effect (data not shown). As a control the apoptotic potential of a PE extract of Lactuca sativa, prepared in the same way and up to $313.0 \mu \mathrm{g} / \mathrm{ml}$, was ineffective (Fig. 1d). Since the PE extract induced apoptosis but not necrosis we further investigated this extract type regarding the apoptotic mechanism involved. Caspase- 3 is one of the key enzymes of apoptosis responsible for the signature-type cleavage of specific target proteins such as the nuclear enzyme poly(ADP-ribose) polymerase (PARP) (18). Therefore, it was investigated whether apoptotic cell death correlated with the activation of caspase- 3 and the cleavage of its target PARP. Incubation of HL-60 cells with $23.2 \mu \mathrm{g}$ PE extract $/ \mathrm{ml}$ cell culture medium (corresponding to $4 \mathrm{mg}$ dried plant) caused the specific cleavage indicative for the activation of caspase- 3 to 19 and $12 \mathrm{kDa}$ fragments within $2 \mathrm{~h}$. After activation of caspase-3 the proteolytic cleavage of the $116 \mathrm{kDa}$ death substrate PARP into a $85 \mathrm{kDa}$ fragment followed within $4 \mathrm{~h}$ of treatment with the extract. This evidenced that caspase- 3 was functional and that the PE extract of $H$. adenotrichum induced caspase-3 dependent apoptosis (Fig. 2a). Tubulin is the major constituent of microtubuli, which facilitate chromosome disjunction during mitosis, and therefore, the affect of tubulin structures is incompatible with functional cell division (19). Hence, it is important to determine whether cytotoxicity can be attributed to tubulin polymerisation as is the case for taxol (20). Alterations in the fine tuned balance of microtubuli polymerisation/de-polymerisation as by taxol were reported to correlate with an increase in the acetylation 

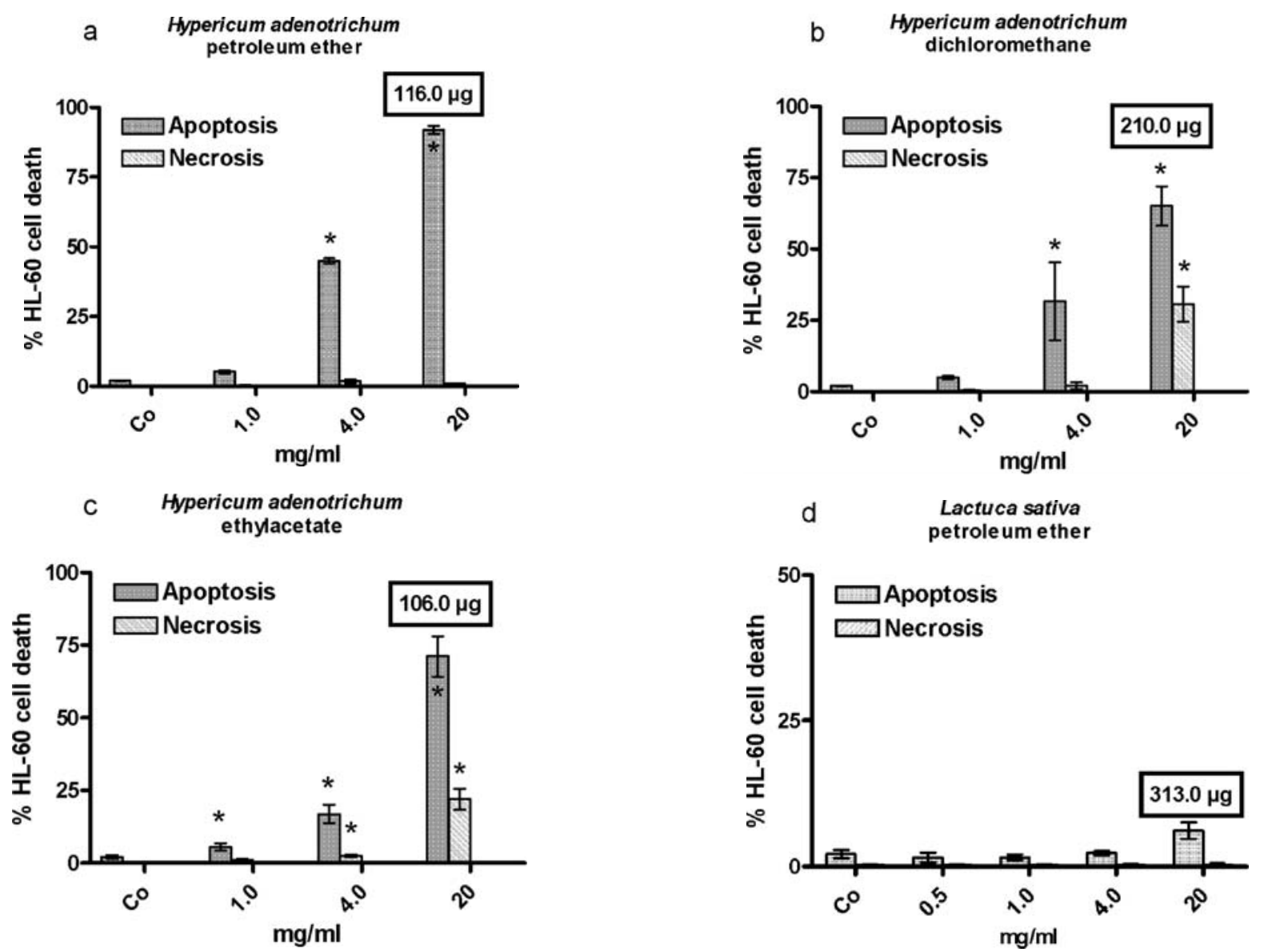

Figure 1. Induction of apoptosis and necrosis by H. adenotrichum extracts. Cells were incubated with the indicated concentrations of (a-c) H. adenotrichum extracts and (d) L.sativa PE extract (mg-amounts correspond to dried plant material; controls were treated with solvent) for $24 \mathrm{~h}$ and then double stained with Hoechst 33258/propidium iodide and viable, apoptotic and necrotic cells determined and counted. Boxed $\mu$ g-amounts refer to dried extract weights per $\mathrm{ml}$ cell culture medium. Error bars indicate SEM, asterisks significance $(\mathrm{p}<0.05)$. Experiments were done in triplicate.

a

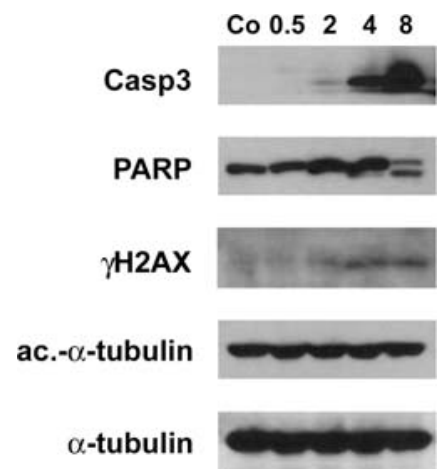

b

Hyperforin

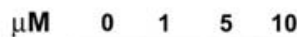

Caspase 3

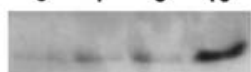

PARP

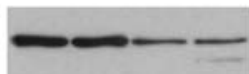

$\gamma \mathrm{H} 2 \mathrm{AX}$

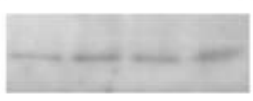

$\beta$-actin
Amentoflavone

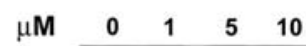

Caspase 3

PARP

$\gamma \mathrm{H} 2 \mathrm{AX}$

$\beta$-actin
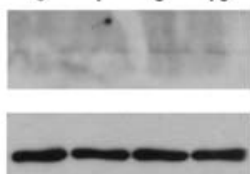
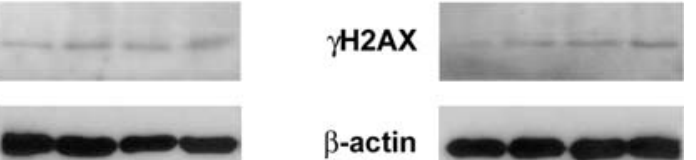

Figure 2. Western blot analysis of indicators of apoptosis and cytotoxicity. HL-60 cells (1x10 cells) were seeded into T-75 tissue culture flasks and allowed to grow for $24 \mathrm{~h}$ when cells were incubated with (a) $23.2 \mu \mathrm{g} / \mathrm{ml} \mathrm{PE}$ extract (corresponding to $4 \mathrm{mg} / \mathrm{ml} \mathrm{dried} \mathrm{plant)} \mathrm{for} 0.5,2,4$, and $8 \mathrm{~h}$, or (b) the indicated concentrations hyperforin and amentoflavone for $8 \mathrm{~h}$. Then, isolated protein samples were subjected to electrophoretic separation and subsequent Western blot analysis. Equal sample loading was controlled by Ponceau S staining, $\alpha$-tubulin-, and $\beta$-actin analysis. The anti-caspase- 3 antibody recognizes only the cleavage product indicating activation. Anti-PARP antibody recognizes the full length form (116 kDa) and the signature-type cleaved product $(85 \mathrm{kDa})$, which is generated by active caspase- 3 , the anti- $\gamma-\mathrm{H} 2 \mathrm{AX}$ antibody detects only the phosphorylated form of core histone variant $\mathrm{H} 2 \mathrm{AX}$, and the specific ac.- $\alpha$-tubulin antibody detects only acetylated forms of $\alpha$-tubulin.

level of $\alpha$-tubulin (21). However, incubation of HL-60 cells with PE extract did not change the acetylation pattern of $\alpha$ tubulin (Fig. 2a). Therefore, this extract presumably did not contain tubulin-targeting activity. To investigate whether apoptosis was triggered through genotoxicity the phos- phorylation status of histone $\mathrm{H} 2 \mathrm{AX}(\gamma-\mathrm{H} 2 \mathrm{AX})$ was analysed, because this core histone variant becomes rapidly phosphorylated in response to DNA double strand breaks (DSB). Incubation of HL-60 cells with $23.2 \mu \mathrm{g}$ PE extract $/ \mathrm{ml}$ induced the phosphorylation of $\mathrm{H} 2 \mathrm{AX}$ within $2 \mathrm{~h}$ and 

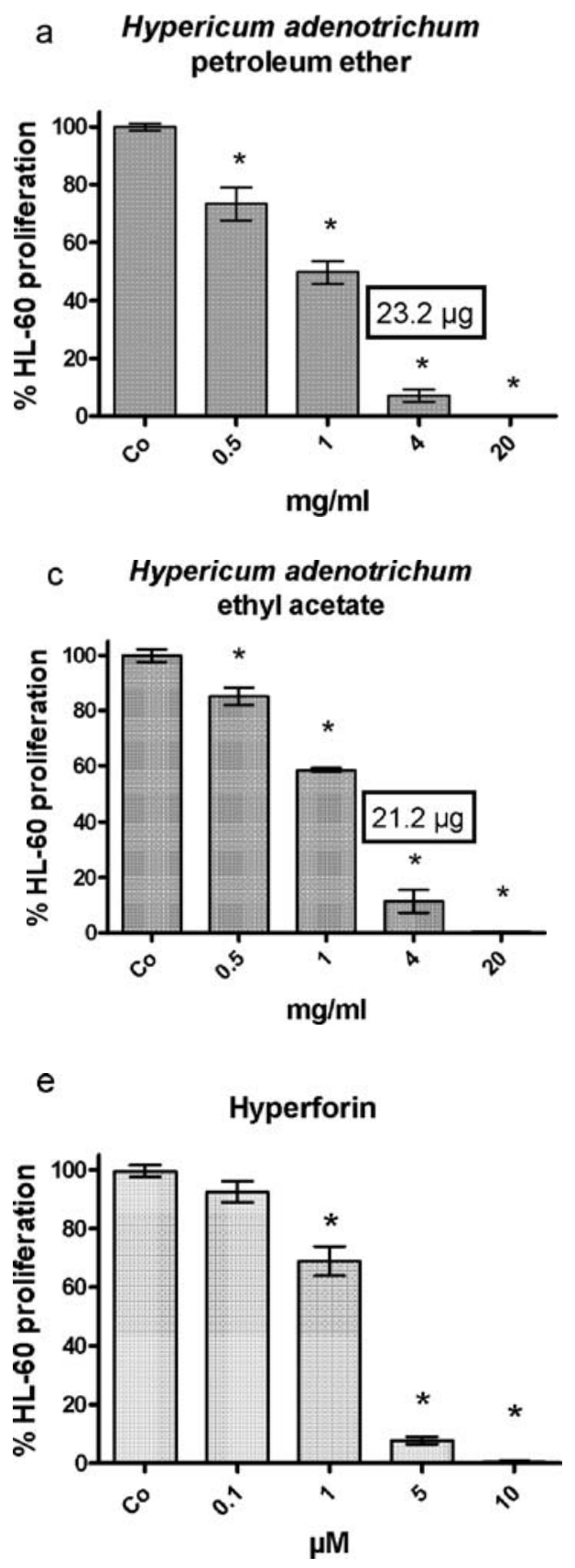

this was concomitant with the onset of caspase- 3 activation (Fig. 2a). H2AX was shown to exert also non-nucleosomal functions, specifically, pro-apoptotic activities in gastrointestinal stromal tumour cells (22). Therefore, the PE extract contained DNA-targeting activities, which may have triggered cell death. In contrast to Crockett et al (12) we detected hyperforin in the dichloromethane extract, however, in a low concentration $(0.088 \%)$ and even less amentoflavone in the ethyl acetate extract of $H$. adenotrichum Spach. Nevertheless, we tested both substances (at several-fold higher concentrations than present in the respective extract types) and analysed the expression of apoptosis in relevant gene products in Western blot analyses. Although hyperforin induced apoptosis at the highest tested concentration $(10 \mu \mathrm{M}$; data not shown) and activated caspase- 3 after $8 \mathrm{~h}, \gamma$-H2AX was not enhanced (Fig. 2b). Therefore, hyperforin induced cell

\section{b Hypericum adenotrichum dichloromethane}
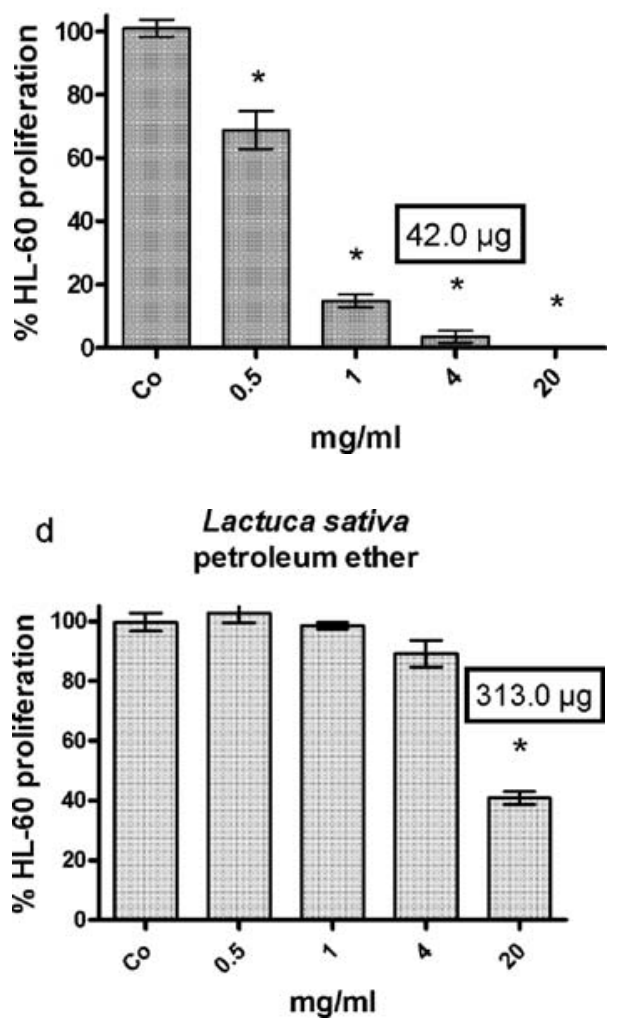

Figure 3. Anti-proliferative effect of extracts of $H$. adenotrichum and Hyperforin. HL-60 cells were seeded into T-25 tissue culture flasks $\left(1 \times 10^{5}\right.$ cells $\left./ \mathrm{ml}\right)$, grown for $24 \mathrm{~h}$ to enter logarithmic growth phase, and incubated with $0.5,1,4$, and $20 \mathrm{mg} / \mathrm{ml}$ (a-c) H. adenotrichum extracts and (d) L. sativa PE extract (mg-amounts correspond to dried plant material), or (e) the indicated concentrations hyperforin. Controls received solvent. Cells were counted after 24 and $48 \mathrm{~h}$ of treatment and the percentage of proliferation within this time span was calculated in comparison to controls. Controls were considered as $100 \%$ proliferating cells. Error bars indicate SEM, and asterisks significance $(\mathrm{p}<0.05)$. Experiments were done in triplicate.

death by another mechanism than the PE extract. Amentoflavone caused a moderate increase of $\gamma-\mathrm{H} 2 \mathrm{AX}$ after $8 \mathrm{~h}$ but this seemed insufficient for caspase- 3 activation and cell death (Fig. 2b).

Anti-proliferative activity of the extracts of $H$. adenotrichum. The extracts inhibited cell growth, whereby the PE extract was more active than dichloromethane and ethyl acetate extracts inhibiting $50 \%$ cell proliferation $\left(\mathrm{I}_{\mathrm{p}} \mathrm{C}_{50}\right)$ at concentrations of $5.8,7.4$, and $6.9 \mu \mathrm{g} / \mathrm{ml}$ cell culture medium, respectively (corresponding to $1.0,0.7$, and $1.3 \mathrm{mg}$ dried plant, respectively; Fig. $3 \mathrm{a}-\mathrm{c})$. The methanol extract was the weakest and therefore, the data are not shown. As a control the PE extract of Lactuca sativa was tested and $313.0 \mu \mathrm{g} / \mathrm{ml} \mathrm{PE}$ extract (corresponding to $20 \mathrm{mg} / \mathrm{ml}$ dried plant) inhibited $\sim 50 \%$ cell proliferation, which suggested that high concentrations of apolar plant extracts may generally contain weak growthinhibitory constituents (Fig. 3d). Hyperforin, dose-dependently and at concentrations that exceeded several-fold the content present in the dichloromethane extract, attenuated cell proliferation (Fig. 3e), whereas amentoflavone did not inhibit cell 
a

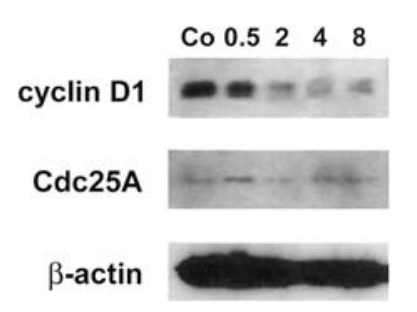

b

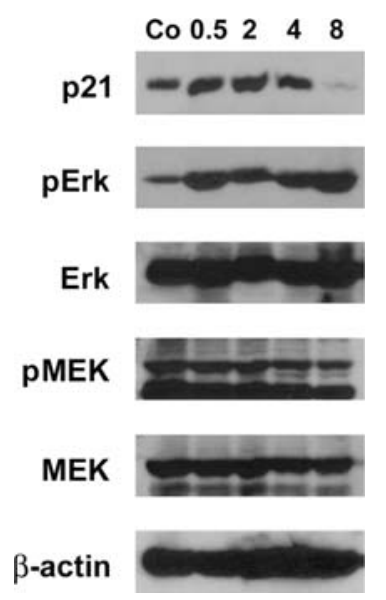

c

\section{Hyperforin}

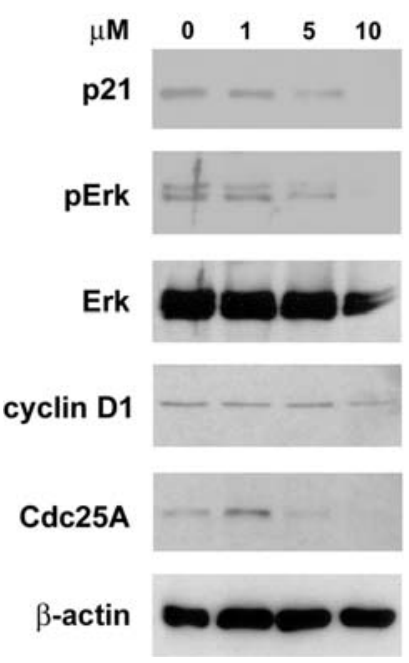

Amentoflavone

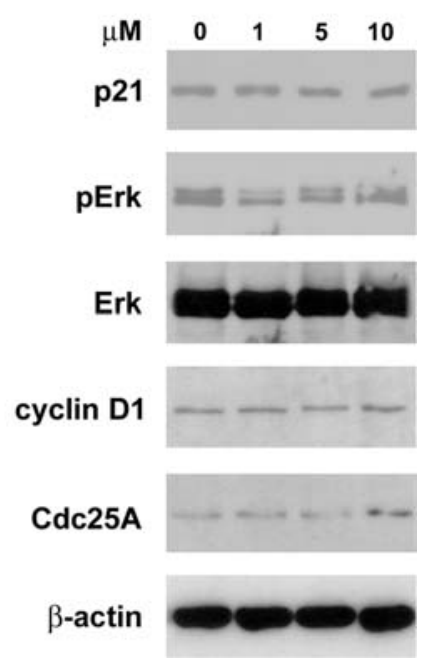

Figure 4. Analysis of cell cycle-related protein and phospho-protein expression. HL-60 cells $\left(1 \times 10^{6}\right.$ cells) were seeded into T-75 tissue culture flasks and allowed to grow for $24 \mathrm{~h}$ when cells were incubated with (a, b) $23.2 \mu \mathrm{g} / \mathrm{ml}$ $\mathrm{PE}$ extract (corresponding to $4 \mathrm{mg} / \mathrm{ml}$ dried plant) for $0.5,2,4$, and $8 \mathrm{~h}$, or (c) the indicated concentrations hyperforin and amentoflavone for $8 \mathrm{~h}$. Then, isolated protein samples were subjected to electrophoretic separation and subsequent Western blot analysis. Following antibodies were used: a) anticyclin D1, and anti-Cdc25A; b) anti-p21, anti-phospho-Erk (pErk), anti-Erk, anti-phospho-MEK (pMEK), anti-MEK. Equal sample loading was controlled by Ponceau $\mathrm{S}$ staining, and $ß$-actin analysis.

proliferation in the tested concentrations $(0.1-10 \mu \mathrm{M}$; data not shown).

Proliferation inhibition correlates with downregulation of cyclin D1 and the upregulation of $p 21$. Since the PE extract was the most potent, we further investigated this extract type regarding its anti-proliferative mechanisms. The expression profiles of positive and negative cell cycle regulators (cyclin D1, Cdc25A, and p21) were analysed by Western blotting in response to $23.2 \mu \mathrm{g} \mathrm{PE}$ extract $/ \mathrm{ml}$ cell culture medium (corresponding to $4 \mathrm{mg}$ dried plant weight). Cyclin D1 was markedly repressed within $2 \mathrm{~h}$ of treatment whereas Cdc25A was not (Fig. 4a). Furthermore, this extract transiently increased the p21 level after $30 \mathrm{~min}$, which dropped below control level after 8 h (Fig. 4b). Since HL-60 cells are p53 deficient (23), the upregulation of $\mathrm{p} 21$, which is a prominent transcriptional target of p53, must have been triggered by another pathway. Besides p53, also the activation of the MEK-Erk pathway was shown to upregulate p21 $(24,25)$. Therefore, MEK-Erk signalling was investigated utilising phospho-specific antibodies. Erk became phosphorylated within $30 \mathrm{~min}$ of treatment with $23.2 \mu \mathrm{g} / \mathrm{ml}$ PE extract and this correlated with the timing of p21 upregulation. The phosphorylated form of Erk persisted at least for $8 \mathrm{~h}$ (Fig. 4b). This is an unusually long period for Erk activation, which is known in other contexts to last only some 10-20 min (26). MEK was constitutively phosphorylated and did not become further induced. Therefore, Erk became auto-phosphorylated (27) or phosphorylated and induced by a kinase different from MEK. Hyperforin halted proliferation through downregulation of Cdc25A, but not cyclin D1 as it was observed with the PE extract, and amentoflavone did not affect the expression of the analysed mitosis and cell cycle regulators (Fig. 4c), which was consistent with its inefficiency to inhibit HL-60 cell proliferation.

\section{Discussion}

Members of the genus Hypericum are used in different folk medicines worldwide and several have been tested against cancer cell growth. Based on the concept that traditional medicinal plants used for wound healing could be crossexamined for anti-tumour properties, we investigated $H$. adenotrichum Spach, which is still used in Turkish traditional medicine for this purpose. The major active principles of Hypericum sp. are hypericin and hyperforin (12). Hypericin has been proposed for photodynamic cancer therapy $(3,4)$ and also hyperforin was shown to inhibit cancer cell growth, to induce apoptosis (5), and to restrain tumour invasion and metastasis (9). In a study of 74 taxa of Hypericum, $H$. adenotrichum was one of the species that lacked rutin and hyperforin, but contained an additional pharmacologically interesting compound, amentoflavone (12). In the subspecies $H$. adenotrichum Spach we nevertheless detected $0.088 \%$ hyperforin in the dichloromethane extract and traces of amentoflavone in the ethyl acetate extract. The PE extract elicited predominantly apoptosis $\left(\mathrm{AC}_{50}=26.0 \mu \mathrm{g}\right.$ extract $/ \mathrm{ml}$ medium, which corresponded to $4.5 \mathrm{mg} / \mathrm{ml}$ dried plant), which was independent of $\mathrm{p} 53$, whereas the dichloromethane and the ethyl acetate extracts also elicited necrosis at a very high rate which is undesired in therapeutic applications. The PE extract-induced apoptosis was preceded by the activation of caspase 3 and the signature-type degradation of its target PARP. The induction of apoptosis is a prominent anticancer property of therapeutic drugs. Since more than $50 \%$ of all cancer types harbour a defective p53 pathway, which is detrimental to successful therapeutic treatment particularly 
with regard to apoptosis induction, compounds which exert anticancer activity independent of p53 are of utmost interest for clinical applications. The PE-extract caused DNA damage as evidenced by $\mathrm{H} 2 \mathrm{AX}$-phosphorylation and hence, the extract contained DNA-targeting activity and this was most likely contributing to the induction of apoptosis, because H2AX was shown to exert pro-apoptotic activities in tumour cells (22). Although hyperforin induced apoptosis it was not responsible for the cytotoxic activity of the PE extract, because it was only present in the dichloromethane extract. Even at the highest tested concentrations amentoflavone was non-toxic. Hypericin was not the cause for cytotoxicity, because the way the experiments were performed excluded the activation of this photo-sensitive compound. Therefore, the PE extract of $H$. adenotrichum Spach contained anti-neoplastic properties that could not be ascribed to bioactive compounds known from other Hypericum species.

Cyclin-dependent kinases (Cdks) are rate-limiting for cell cycle progression and a common feature of potent anticancer drugs is their cell cycle inhibitory property thereby attenuating or blocking cell proliferation. In this respect, the PE extract was most active followed by the ethyl acetateand the dichloromethane extract (with reference to extract weight). Two independent mechanisms of cell cycle arrest were identified: i) the induction of $\mathrm{p} 21^{\mathrm{Cip} / \mathrm{Waf}}$ and therefore, most likely the inhibition of $\mathrm{Cdk} 2$. The major regulator of the p21 tumour suppressor protein is p53, but also Erk was reported to induce p21 $(24,25)$ and here it was demonstrated that the PE extract activated Erk in p53-deficient HL-60 cells (23); ii) the downregulation of cyclin D1 and hence, the inhibition of Cdk4 and/or Cdk6 (28-30). Cyclin D1 is an oncogene that is overexpressed in various cancer types (31) and therefore, cyclin D1 is a target for anti-neoplastic therapy. Thus, a prominent anti-cancer property present in the PE extract of $H$. adenotrichum Spach was discovered. Interestingly, neither amentoflavone nor hyperforin induced p21 or suppressed the expression of cyclin D1. Hyperforin arrested HL-60 cell growth likely through the repression of another cell cycle regulator and oncogene, Cdc25A. Cdc25A expression remained unaffected when HL-60 cells were exposed to the PE extract and this indicated that either synergies between low-activity or low-abundance components caused the cell cycle arrest, or, that unexplored compounds that were present in the PE extract were responsible for the anti-neoplastic effects.

Leukaemia is among the most common cancers worldwide. A major drawback of chemotherapeutic treatment in most cases is the development of resistances e.g. against AraC $(32,33)$ and therefore, the chemotherapeutic armamentarium is limited and new concepts for adjuvant and second treatment options are needed. This justifies further investigations of this promising plant extract.

\section{Acknowledgements}

Thanks to Toni Jäger who helped to prepare the figures. The authors are greatly indebted to TUBITAK and ADU-BAP for providing partial financial support to A.Ö., and the Fonds for Innovative Interdisciplinary Cancer Research for grants to M.F.S. and G.K.

\section{References}

1. Cragg GM, Newman DJ and Yang SS: Natural product extracts of plant and marine origin having antileukemia potential. The NCI experience. J Nat Prod 69: 488-498, 2006.

2. Baytop T: 'Türkiyede Bitkiler ile Tedavi'. Istanbul University Press, Faculty of Pharmacy No: 3255, 1999.

3. Schempp CM, Haarhaus BS, Termeer CC and Simon JC: Hypericum photo-induced apoptosis involves the tumor necrosis factor-related apoptosis-inducing ligand (TRAIL) and activation of caspase-8. FEBS Lett 493: 26-30, 2001

4. Agostinis P, Vantieghem A, Merlevede W and de Witte PAM: Hypericin in cancer treatment: more light on the way. Int $\mathrm{J}$ Biochem Cell Biol 34: 221-241, 2002.

5. Hostanska K, Reichling J, Bommer S, Weber M and Saller R: Hyperforin a constituent of St John's wort (Hypericum perforatum $L$.) extract induces apoptosis by triggering activation of caspases and with hypericin synergistically exerts cytotoxicity towards human malignant cell lines. Eur J Pharm Biopharm 56: 121-132, 2003.

6. Martarelli D, Martarelli B, Pediconi D, Nabissi MI, Perfumi M and Pompei P: Hypericum perforatum methanolic extract inhibits growth of human prostatic carcinoma cell line orthotopically implanted in nude mice. Cancer Lett 210: 27-33, 2004.

7. Wilairat R, Manosroi J, Manosroi A, Kijjoa A, Nascimento MSJ, Pinto M, Silva AMS, Eaton G and Herz W: Cytotoxicities of xhantones and cinnamate esters from Hypericum hookerianum. Planta Med 71: 680-682, 2005.

8. Schempp CM, Kiss J, Kirkin V, Averbeck M, Haarhaus BS, Kremer B, Termeer CC, Sleeman J and Simon JC: Hyperforin acts as an angiogenesis inhibitor in vitro and in vivo. Planta Med 71: 999-1004, 2005.

9. Dell Aica I, Caniato R, Biggin S and Garbisa S: Matrix proteases, green tea and St. John's wort: biomedical research catches up with folk medicine. Clin Chim Acta 381: 69-77, 2007.

10. Ferraz A, Faria, DH, Benneti, MN, da Rocha AB, Schwartsmann G, Henriques A and von Poser GL: Screening for antiproliferative activity of six southern Brazilian species of Hypericum. Phytomedicine 12: 112-115, 2005.

11. Skalkos D, Stavropoulos NE, Tsimaris I, Gioti E, Stalikas CD, Nseyo UO, Ioachim E and Agnantis NJ: The lipophilic extract of Hypericum perforatum exerts significant cytotoxic activity against T24 and NBT-II urinary bladder tumor cells. Planta Med 71: 1030-1035, 2005.

12. Crockett SL, Schaneberg B and Khan IA: Phytochemical profiling of new and old world Hypericum (St. John's Wort) species. Phytochem Anal 16: 479-485, 2005.

13. Krenn L, Presser A, Pradhan R, Bahr B, Paper DH, Mayer KK and Kopp B: Sulfemodin 8-O-beta-D-glucoside, a new sulfated anthraquinone glycoside, and antioxidant phenolic compounds from Rheum emodi. J Nat Prod 66: 1107-1109, 2003.

14. Marchart E, Krenn L and Kopp B: Quantification of the flavonoid glycosides in Passiflora incarnata by capillary electrophoresis. Planta Med 69: 452-456, 2003.

15. Dolezal K, Popa I, Krystof V, Spíchal L, Fojtíková M, Holub J, Lenobel R, Schmülling T and Strnad M: Preparation and biological activity of 6-benzylaminopurine derivatives in plants and human cancer cells. Bioorg Med Chem 14: 875-884, 2006.

16. Grusch M, Polgar D, Gfatter S, Leuhuber K, Huettenbrenner S, Leisser C, Fuhrmann G, Kassie F, Steinkellner H, Smid K, Peters GJ, Jayaram HN, Klepal W, Szekeres T, Knasmuller S and Krupitza G: Maintenance of ATP favours apoptosis over necrosis triggered by benzamide riboside. Cell Death Differ 9: 169-178, 2002 .

17. Huettenbrenner S, Maier S, Leisser C, Polgar D, Strasser S, Grusch M and Krupitza G: The evolution of cell death programs as prerequisites of multicellularity. Mutat Res 543: 235-249, 2003.

18. Fernandes-Alnemri T, Litwack G and Alnemri ES: CPP32, a novel human apoptotic protein with homology to Caenorhabditis elegans cell death protein Ced-3 and mammalian interleukin-1 beta-converting enzyme. J Biol Chem 269: 30761-30764, 1994.

19. Piperno G and Fuller M: Monoclonal antibodies specific for an acetylated form of alpha-tubulin recognize the antigen in cilia and flagella from a variety of organisms. J Cell Biol 101: 2085-2094, 1985

20. Geney R, Sun L, Pera P, Bernacki RJ, Xia S, Horwitz SB, Simmerling CL and Ojima I: Use of the tubulin bound paclitaxel conformation for structure-based rational drug design. Chem Biol 12: 339-348, 2005. 
21. Xiao H, Verdier-Pinard P, Fernandez-Fuentes N, Burd B Angeletti R, Fiser A, Horwitz SB and Orr GA: Insights into the mechanism of microtubule stabilization by Taxol. Proc Natl Acad Sci USA 103: 10166-10173, 2006.

22. Liu Y, Parry JA, Chin A, Duensing S and Duensing A: Soluble histone $\mathrm{H} 2 \mathrm{AX}$ is induced by DNA replication stress and sensitizes cells to undergo apoptosis. Mol Cancer 7: 61, 2008.

23. Biroccio A, del Bufalo D, Ricca A, D'Angelo C, D'Orazi G, Sacchi A, Soddu S and Zupi G: Increase of BCNU sensitivity by wt-p53 gene therapy in glioblastoma lines depends on the administration schedule. Gene Ther 6: 1064-1072, 1999.

24. Park KS, Jeon SH, Oh JW and Choi KY: p21Cip/WAF1 activation is an important factor for the ERK pathway dependent anti-proliferation of colorectal cancer cells. Exp Mol Med 36: 557-562, 2004

25. Facchinetti MM, De Siervi A, Toskos D and Senderowicz AM: $\mathrm{UCN}-01$-induced cell cycle arrest requires the transcriptional induction of p21(waf1/cip1) by activation of mitogen-activated protein/extracellular signal-regulated kinase kinase/extracellular signal-regulated kinase pathway. Cancer Res 64: 3629-3637, 2004.

26. Ebner HL, Blatzer M, Nawaz M and Krumschnabel G: Activation and nuclear translocation of ERK in response to ligand-dependent and -independent stimuli in liver and gill cells from rainbow trout. J Exp Biol 210: 1036-1045, 2007.

27. Pimienta G and Pascual J: Canonical and alternative MAPK signaling. Cell Cycle 6: 2628-2632, 2007.
28. Draetta $\mathrm{G}$ and Beach D: Activation of cdc2 protein kinase during mitosis in human cells: cell cycle-dependent phosphorylation and subunit rearrangement. Cell 54: 17-26, 1988.

29. Pines J: Cyclins: wheels within wheels. Cell Growth Differ 2: 305-310, 1991

30. Lingfei K, Pingzhang Y, Zhengguo L, Jianhua G and Yaowu Z: A study on p16, pRb, cdk4 and cyclinD1 expression in nonsmall cell lung cancers. Cancer Lett 130: 93-101, 1998.

31. Alao JP: The regulation of cyclin D1 degradation: roles in cancer development and the potential for therapeutic invention. Mol Cancer 6: 24, 2007.

32. Maier S, Strasser S, Saiko P, Leisser C, Sasgary S, Grusch M, Madlener S, Bader Y, Hartmann J, Schott H, Mader RM, Szekeres T, Fritzer-Szekeres M and Krupitza G: Analysis of mechanisms contributing to AraC-mediated chemoresistance and re-establishment of drug sensitivity by the novel heterodinucleoside phosphate 5-FdUrd-araC. Apoptosis 11: 427-440, 2006.

33. Strasser S, Maier S, Leisser C, Saiko P, Madlener S, Bader Y, Bernhaus A, Gueorguieva M, Richter S, Mader RM, Wesierska-Gadek J, Schott H, Szekeres T, Fritzer-Szekeres M and Krupitza G: 5-FdUrd-araC heterodinucleoside re-establishes sensitivity in 5-FdUrd- and AraC-resistant MCF-7 breast cancer cells overexpressing ErbB2. Differentiation 74: 488-498, 2006. 